\title{
Bhoodan-Based Corporate Citizenship: Corporate Accountability Based on Serving and Empowering Land-Owners and Users
}

\author{
By Siddharth Mohapatra* \& Pratima Verma ${ }^{\dagger}$
}

This paper attempts to conceptualize a corporate citizenship program in the context of land acquisition for commercial purposes in India. At present, instances of land acquisition related sustainability challenges are rampant, which have affected both business and society. Land related socio-economic impasses were also acute especially in India's post-independence era in the 1950's. Bhoodan (land-gift) movement, a fusion of servant leadership and social entrepreneurship, was by and large effective to address them. Considering its socio-cultural relevance, business can employ the tenets of Bhoodan to streamline the present situation. In this regard, we propose the Bhoodan-based corporate citizenship that can serve and empower land-owners and users, facilitate spontaneous land transfers, and streamline land acquisition for commercial purposes in India. Implications for research and practice are discussed.

Keywords: Bhoodan-based corporate citizenship (BbCC), land acquisition for commercial purposes, India, servant leadership, social entrepreneurship, spontaneous land transfers

\section{Introduction}

"Responsibility is the price of greatness." - Winston Churchill

The interests of business and society are intertwined. Corporate citizenship is a means in this regard e.g. (Schwab 2008). Corporate citizenship, a form of business ethics, underlines the social role of business (Crane et al. 2008). In line with the political concept of citizenship, it emphasizes on an organization's rights and duties in and for the business community (Logsdon and Wood 2002), i.e., business should act as a responsible citizen. However, business often sidelines its social responsibility especially in developing countries (Munshi and Kurian 2007: 439). The current contentious issue of land acquisition for commercial purposes in India (hereafter land acquisition) is such an instance.

India is the fastest growing major economy in the world (International Monetary Fund, IMF 2016). However, the current state of land acquisition is inefficient, unethical, and even illegal on many occasions. For example, land transfer is often marred by litigations over compensation and regulatory impediments obstructing voluntary land transactions (Singh 2012). Similarly, crony capitalism in the context of land acquisition is "one of the greatest dangers to the growth of developing countries..., which is harmful to free enterprise,

\footnotetext{
*Assistant Professor, Indian Institute of Management Kozhikode, India.

†Professor, Alliance University, India.
} 
opportunity and economic growth [and also] ... democratic expression.... [It is not only a problem... [of] individual ethics ... [but also] the [unethical] system we have" (Raghuram Rajan, quoted in The Times of India 2014). Streamlining unethical land acquisition business practices needs to address systemic bottlenecks.

Land acquisition mainly serves the interests of companies (Lobo and Kumar 2009). It often exerts pressure tactics, like big bucks investment appeals or threats of relocation, to obtain resource-rich land (Sethi 2002). It seeks lenient land regulations to circumvent socio-environmental impact analysis, fast-tracking projects, and lowering costs (Ahmed and Varshney 2012). The situation has further deteriorated due to contentious tenancy status, lack of consensus based land acquisition laws (Chakravorty 2013), land grabbing instances supported by business (Drèze and Sen 2013), public land being leased or sold to influential companies on favorable terms (Ghatak and Ghosh 2011), and subpar compensation and rehabilitation measures for land-owners and users (Chakravorty 2013). This has two implications. One, business is the dominant player in the land acquisition process. Two, land acquisition is marred by poor stakeholder management. India in turn ranks lowly on many business ethics indicators. For example, India is placed at 81 among 180 countries in Transparency International's (2018) Corruption Perception Index; unethical land acquisition practices do affect corruption significantly in India (Sahoo et al. 2014).

Since time immemorial, land is a contentious issue in India. The powerful socio-economic players have often suppressed the legitimate rights of the imperceptible ones while harnessing prosperity from land (Drèze and Sen 2013). The current socio-economic impasses related to land acquisition is not different either wherein companies have connived with the government to exploit the landowners and users. However, to have the rights to remain a going concern, business should discharge its duties like a good citizen-corporate citizenship (Crane et al. 2008). With the backdrop of the current unsustainable land acquisition practices, we attempt to conceptualize a corporate citizenship program to address land acquisition related impasses.

In the aftermath of independence, the Bhoodan (land-gift) movement was lunched to address a similar situation. Drawing parallels between India now and then, we borrow tenets from Bhoodan into the domains of corporate citizenship to undertake this study that is organized as follows. We first review the current state of land acquisition from social, political, and economic perspectives. Then we analyze Bhoodan under the rubrics of servant leadership and social entrepreneurship. We subsequently discuss the role of corporate citizenship based on Bhoodan-Bhoodan-based corporate citizenship (BbCC) - as enabling citizenship rights to land-owners and users. Thereafter, following the literature on corporate citizenship especially Crane et al.'s (2008) extended corporate citizenship, we conceptualize the Bhoodan-based corporate citizenship program that is led by business, which can serve and empower the land-owners and users, facilitate spontaneous land transfer, and create a win-win situation for business and society. 


\section{Study Design and, Research Method and Methodology}

Although land acquisition related poor stakeholder management is a recent issue, its roots lie in the social and cultural milieu of India. Bhoodan was an attempt to address various historical injustices underlying land related socioeconomic impasses. As historical data provide critical contextual link of the past to the present, we have undertaken historical research and used bibliographic method (Howell and Prevenier 2002). To minimize literature selection bias particularly spectrum bias and random error, we have reviewed studies on multiple stakeholders and undertaken dual review respectively (e.g. Collier 1995).

Further, BbCC is a corporate citizenship program, which is based on Bhoodan. This implies that the initial strategy to reach the final state is largely unknown and should ideally be deduced from existing concepts (see Watanabe 1972). We have employed retroductive approach as the methodology and drawn tenets from servant leadership and social entrepreneurship to conjecture event causality of Bhoodan and predict generative causality of BbCC respectively (see Mingers and Standing 2017). Retroduction is a viable means in studies like ours because it is a theory building study, not theory testing one (McKay 1976).

\section{The Current State of Land Acquisition in India}

Land acquisition for economic development in India has affected business, government, people and environment (Ahmed and Varshney 2012). This is elaborated as follows.

\section{Land Acquisition and, People and Environment}

Agriculture currently employs nearly 56.6 percent of the population in India but accounts for only 15 percent of GDP (Planning Commission of India 2014). Hence, policymakers encourage transition from agriculture to manufacturing and service sectors (Bhagwati and Panagariya 2013). Since independence, India has embarked on urbanization and industrialization for economic growth, which have led to large scale acquisition of land (Chakravorty 2013). Between 1951 and 1995, more than 50 million acres of land, nearly 10 percent of India's usable land, were acquired and converted for these projects (Fernandes 2004). More than 60 million people have lost land, livelihood, common properties, and leased contracts between 1947 and 2000 (Fernandes 2008).

In many instances of land acquisition, land-owners and users merely remain mute spectators (Sarkar 2012). The following remarks by a tribal, affected by land acquisition for mining, are disturbing.

"We worshipped the forest god. We got all our firewood from here. This place was green, now it is black with dust.... When agricultural land is lost, what are we supposed to eat? Coal" (Amnesty International 2016: 62)? 
There are many such instances in India's rural and tribal areas (Drèze and Sen 2013). Although compensation is paid in urban areas, it often gets mismanaged. The story of a farmer in Gurugram, which has offices of 300 of Fortune 500 companies and is the IT hub of North India, tells it succinctly (Business Standard 2013).

"I got ... [300 thousand US dollars] by selling nearly three acres of agricultural land [that is part of urban Gurugram now].... I purchased six acres [of land in rural Gurugram,] ... built ... a ... bungalow and bought a SUV.... I never thought that money would finish one day.... Now I am working as a private security guard in a building on my own land."

On one hand, farmers are in a hurry to quit farming, move to the city, and create fortunes for themselves; on the other hand most of them being illiterates do not understand the long-term implications of selling land (Narain 2009). They often overspend compensation money without creating regular income sources and lose everything (Levien 2011). Hence, land acquisition related compensation, resettlement, and rehabilitation needs to be improved.

On many occasions, compensations are meagre and erratic. The government, to keep project costs low, often sets low acquisition prices (Chakravorty 2016). In every six out of ten cases appealed against low acquisition prices, the Supreme Court of India increases compensation, sometimes up to ten times of the original amount (Hindustan Times 2016). Often, the farmer receives only one quarter of the cost of the land as compensation and the rest goes as subsidy to the buyer (Hindu 2015). Discontents emerge even after land is transferred; as market prices soar due to the usual post-acquisition development spree, erstwhile owners get dejected (Levien 2011). In the process, millions of long-standing land dispute litigations are pending in courts. Land related litigations usually take decades for settlement (Supreme Court of India 2016). Hence, apart from compensation, they involve loss of pay, wasted business opportunities, legal expenses, and emotional ordeals (Chakravorty 2016).

Adivasis (aborigines) and dalits (untouchables) are the worst affected in land acquisition (Drèze and Sen 2013). Their land is not considered acquired because most of them use common property resources, like forest and sea, for livelihood (Chakravorty 2016). These land acquisitions are less likely to be challenged in courts (Ghatak and Ghosh 2011). Consequently, they lose traditional livelihoods and do not get compensation. For example, the fishermen from the displaced fishing villages near Adani Group's Mundra port and SEZ fear that they would not be given access to the sea once the port is fully functional. Thus, compensations do not include lost livelihoods. Ghatak and Ghosh (2011: 66) argues that "the market price is not an adequate anchor for compensation, and this ad hoc formula will guarantee neither social justice nor efficient use of a scarce resource, notwithstanding its pro-poor appearance." Consequently, many land-owners and users suffer immensely and even commit suicide (Dias 2009). Landownership being an emotional issue for Indians, it is also argued that the valuation of land should not only be determined by the opportunity costs or market prices but also 
additional factors, like emotional attachments to and social identity arising from landholdings (Porwal and Singh 2011).

Furthermore, On many occasions, community-level cronyism, where the government and corporations create divisions by favoring some groups and ignoring others, has also jettisoned collective action by the affected people that is usually effective in Indian (Levien 2011). Thus, the cost of land acquisition to individuals, communities, and environment are ominous.

\section{Land Acquisition and Government}

Till 2013, land acquisition in India was governed by the colonial-era Land Acquisition Act of 1894. Post-independence, eminent domain was used to avoid huge transaction costs. State often forcibly acquired private properties for public purpose by paying just compensations even if the owner did not want to sell (Chakravorty 2016). Hence, it was an anti-people law. In 2013, the Indian parliament passed the Right to Fair Compensation and Transparency in Land Acquisition, Rehabilitation and Resettlement Act, 2013 (RFCTLARR13), with stringent clauses against forced acquisition (Chakravorty 2016). Under RFCTLARR, land acquisition roughly used to take 4-5 years (NITI Aayog, n.d.). Hence it was viewed as antibusiness and antidevelopment. This prompted the present government to amend (RFCTLARR13) to RFCTLARR (Amendment) Bill, 2015 (RFCTLARR15) (Chakravorty 2016).

Amendments like removing the mandatory social impact assessments and 80 percent consent of community before acquiring were aimed at reducing the acquisition time, lowering the indirect costs of acquisition, and attracting investment (Chakravorty 2016). Opposition parties have accused the government of indulging in cronyism; its passage in the Indian parliament through consensus is still a daunting task (Indian Express 2016). To continue economic development, some state governments are bypassing existing laws, even promulgating their own laws to fast-track land acquisition, flouting social and environmental norms on many occasions (Reuters 2016). Such fast-paced reforms however can create sustainability challenges. For instance, there are arguments like "land acquisition by the Indian state ... [has been] a profoundly regressive process - it redistributed the benefits of land use from the poor to the less-poor and the non-poor" (Chakraborty 2016: 55)—instances of Raghuram Rajan's state-sponsored cronyism (Times of India 2014).

Furthermore, land acquisition fall under the jurisdiction of both center and states. With no consensus in sight, it can lead to constitutional crises if some state governments violate RFCTLARR13 and the central government, say from a different political party, contests it; this would ultimately undermine the federal structure of India (Goswami 2016). Considering various political, constitutional, and governance implications of land acquisition, the vice chairman of the central planning commission of India in the recent past has said, "Land acquisition [is] a difficult task in India” (Economic Times 2015). 


\section{Land Acquisition and Business}

In the recent past, there have been violent agitations against companies acquiring land, notably Tata Motors in Singur, Posco in Jagatsinghpur, Mukesh Ambani Group in the outskirts of Mumbai, and Adani Group in Mundra. Even there are organized armed rebellions against business in the Naxalite infested areas in central India (Hardiman 2003). Nearly 90 percent of all the land acquisitions are for government projects (Lobo and Kumar 2009). However, many of these projects like mining, energy, industrial corridors, smart cities, high-speed rails, SEZs, ports, and airports mainly benefit business. Thus, questions are increasingly being raised concerning why the state should acquire land for business (The New York Times 2015, cf. NITI Aayog, n.d.).

Streamlining land acquisition is easier said than done because the public is still distrustful of government and companies due to past abuses (e.g., Nielsen 2015). Moreover, due to the proposed changes in RFCTLARR15, people are apprehensive that their land would be forcibly acquired for meagre compensations (The New York Times 2015). Interestingly, there are estimations that people could make a lot of money, up to " 25 times or maybe 100 times more than they're going to get from farming in perpetuity," if they transfer land (The New York Times 2015). This however can happen only if RFCTLARR15 is implemented fairly. Tracing the history of legislation-based, state-governed, top-down land acquisition approach in India presents a gloomy picture in this regard (Somayaji and Talwar 2011). Hence, to streamline land acquisition, there are growing demands to take various stakeholders into confidence (Bardhan 2011, Michael and Baumann 2016, Narain 2009, Nielsen 2015). A similar situation prevailed in the aftermath of India's independence, which was addressed by Vinoba Bhave through the Bhoodan movement (Bornstein 2007).

\section{Bhoodan: A Voluntary Land Reform Movement in India}

Vinoba Bhave was an important figure in the Indian freedom struggle. He is the recipient of the first Ramon Magsaysay Award for Community Leadership and the Bharat Ratna, India's highest civilian award (Figueroa 1997). He had taken the vow to bestow selfless service to the mankind (Jaffrelot 2012). In March 1948, he, along with many other followers of Gandhi, created the Sarvodaya Samaj or the society of welfare-for-all (Jaffrelot 2012) to realize Gandhi's dream India- the Ram Rajya ${ }^{1}$.

At the time of independence, India was an agrarian society (Singh 2009). Nearly 70 percent of its population lived in villages and agriculture was the single most important factor influencing the growth of the national income (Singh 2009). "In ... [an agrarian] society land is more than just another factor of production.... $[\mathrm{I}] \mathrm{t}$ is the long term security of the family against the hazards of life, and it is part of the social status of the family within village or community" (Ellis 1993: 8).

\footnotetext{
${ }^{1}$ A utopian society without misery, sorrow, and distress
} 
Hence, landownership was not an economic but also social and cultural factor in India. Over 60 percent of the households in rural India however were either landless or owned meagre acres of land (Chandra et al. 2008: 509). The land-man ratio in rural India was 0.92 acres (per capita), which was considered very low in comparative standards (Chandra et al. 2008: 509). Tenancy made this situation more complicated, comprising of complex layers of possession, leasing and tilling. This was due to the zamindars (absentee landowners) in the Northeast, small landholding owner-cultivators in the Northwest and varying degrees of ownership and leased-farming in the South, West, and Central India (Varshney 1998). Moreover, upper caste people owned more land than the lower caste (Singh 2009). Furthermore, the British colonizers arbitrarily distributed land rights to rich landlords through Permanent Settlement Act of 1793 mainly to garner their support toward the continuance of the British rule in India (Drayton 2000). As a result, the lower stratum of society was subjected to the most grievous oppression. Abysmally, the British colonizers treated India as a raw material producing colony and a consumer base; they did not do much toward land reform (Drayton 2000). There were many uprisings against landlords, which continued in the postindependent India (Brass 1994).

To create a just and equitable society, Vinoba embarked on a series of reformist movements under auspices of the Sarvodaya Samaj. In 1951, in response to growing peasant revolutions all around India, he launched Bhoodan - an extraordinary and unprecedented socio-economic developmental endeavour for 'land reform' in the recorded history - to contain violence through non-violence (Chandra et al. 2008). It was an attempt to solicit voluntary land transfer to create an equitable society (Dutta Mishra and Narayanasamy 2009: 252).

"In a just and equitable ... society, land must belong to all. That is why we do not beg for gifts, but demand a share to which the poor are rightly entitled. The main objective is to propagate the right thought, by which social and economic maladjustments can be corrected without serious conflicts."

Vinoba, with many fellow Gandhians, walked through villages, persuading landlords and landowners to donate land to landless cultivators to restore amity in society (Dutta Mishra and Narayanasamy 2009).

The mission of Bhoodan was "to bring about a sarvodaya social orderGandhi's vision of a stateless society devoted to the welfare of all and founded on non-violence, equality and decentralization" (Church 1975: 94). Land was donated voluntarily and distributed according to need (Figueroa 1997). Although by the end of 1956, more than 4 million acres of land had been collected against a target of 50 million acres, "it was enough for people to consider the movement one of the most significant in India's history" (Figueroa 1997: 44). Additionally, to scale up Bhoodan, he launched Gramdan (village-gift), Jivandan (Gift of life), Sampattidan (gift of the wealth), Shramdan (gift of labour), Shanti Sena (Army for Peace), and Sarvodaya-Patra (the pot where every household gives handful of grain daily) (Church 1975). 


\section{Bhoodan: Servant Leadership Influenced Social Entrepreneurship}

According to William Drayton, the founder of Ashoka, "[Vinoba is] a social entrepreneur" (Bornstein 2007: 53). Social entrepreneurship is a fusion of altruism and entrepreneurship (Nicholls and Cho 2006). Social entrepreneurs "see a bad situation, envisage a better one, and work out how to get from ... [bad] to [better]" (Clark 2009: 20-21). They identify opportunities, strategize innovative means, and mobilize resources (Economy 2002) to create "sustainable improvements" (Dees 1998: 5) and diversify to create further improvements (Dees et al. 2002). Lastly, they spread these transformations to other regions to create multiplier and ripple effects (Bornstein 2007). As regard their success, "quality of motivation" is crucial, which are: a willingness to self-correct (themselves and their social enterprises), sharing credits, breaking free from established structures, going beyond disciplinary boundaries, working quietly yet steadfastly, and having strong ethical impetuses (Bornstein 2007). To be effective, social entrepreneurship needs the spirit of servant leadership (Kitzi 2002, Greenleaf 2002[1977]). The key elements of social entrepreneurship therefore are: change agents, social problems, opportunity, innovation and resource mobilization, sustainability, transformation, social impact, multiplier effect, and, importantly, servant leadership (Meehan 2004). Next, we discuss them in the context of Bhoodan.

Immediately after India's independence, Vinoba founded the Sarvodaya Samaj to create an equitable society. Hence, he was a visionary and a change agent. He identified that "the solution to India's problems ... [was] land distribution" (Time 1958). Thence, he created Bhoodan. His target was to get 50 million acres of land in five years (1953-57), to be distributed among 50 million landless (Venkatasubbiah 1961). In this way, after identifying the problem, he seized the opportunity to create social change. Importantly, he diversified Bhoodan to increase its effectiveness.

Vinoba had renounced all his material property. Gandhi once had remarked, "Vinoba ... has acquired a degree of spirituality and asceticism that took me years of patient labour to attain" (Jayapalan 2003: 219-220). He had charisma and massappeal, mainly because he was regarded as Gandhi's spiritual heir (Sabin 2002). Moreover, he featured in the Time (1953) magazine cover. His strength was to pull people toward Bhoodan. To encourage land donation, he appealed the landlords as follows: "Like air and water, land belongs to God. To claim it for oneself alone is to oppose the very will of God. And who can be happy if they oppose His will" (Tennyson 1955: 71)? In this manner, it attempted the "ideas of trusteeship and fraternity as means of [social] reform, rather than legislations" (Brown 2000: 167).

Bhoodan was launched from the Telangana region, after the state government of Andhra Pradesh, the Indian Army, and landlords ruthlessly suppressed the Telangana Movement (1946-51) — one of the most widespread, fierce, and long lived peasant movements - in 1951 (Brass, 1994). Thus, the timing was apt to send a strong message to the government and landlords about their crimes and the place was appropriate to show his solidarity with the landless. Vinoba's creativity was his simplicity. He used common man's language and day to day communication style to mobilize resources. 
'To those who have land ... [Vinoba] says: "I have come to loot you with love. If you have four sons, consider me as the fifth, and accordingly give me my share." To impoverished tenants and landless laborers ... [he] says: "We are all members of a single human family" (Time 1953).

Sustainability of Bhoodan lay on its multiple stakeholders and the emphasis on giving. For instance, Vinoba not only accepted 100,000 acres from a Maharajah (king), but also a tiny patch of one fortieth of an acre of land donated by a Telangana peasant who owned only one acre himself (Time 1953). Thus, he engaged the common man as well as their erstwhile rulers in Bhoodan. He also involved the policy makers in it. For instance, Jawaharlal Nehru, the first Prime Minister of India, acknowledged that land belonged to all and private ownership must end, and sought Vinoba's help "to find for India a way of raising food production and the peasant standard of living" (Time 1958).

The social impact of Bhoodan was mixed, though. By 1967, when Vinoba withdrew himself from Bhoodan, 4.27 million acres of land were donated (Dutta Mishra and Narayanasamy 2009). 1.19 million acres of land were distributed (which was far more than what the government had done), 1.73 million acres were barren, and 1.34 million acres remained undistributed (which included disputed land) (Dutta Mishra and Narayanasamy 2009). In most of the cases, landlords often donated land that was either uncultivable or litigated (Dutta Mishra and Narayanasamy 2009). The land thus obtained and distributed were far less than the target of 50 million acres. Yet, Bhoodan succeeded "in bringing about [changes] in [landlords'] attitudes through [their] feelings of guilt" (Weber 2004: 154).

Furthermore, many national and state level land reform legislations were promulgated under the direct and indirect influence of Bhoodan. The Zamindari Abolition Act (1950-70) under which intermediaries (mainly the landlords) between the State and the actual tillers were removed, thereby bringing nearly 20 million cultivators into direct contact with the government and some 5.77 million hectares (or ten thousand square meters) of land was distributed in the process (NCAS 2005). Several state laws were enacted between 1960 and 1972 to initiate tenancy reforms as regard security of land tenure, rent regulation, right of ownership, and land ceiling limits (NCAS 2005). Bhoodan also created multiplier effects by influencing many socio-economic developmental programs in Asia and Africa; especially was instrumental in the creation of the Sri Lankan Sarvodaya Movement (Melkote and Steeves 2001) that strived for various grassroots empowerment programs in Sri Lanka.

Furthermore, social entrepreneurship attempts to create permanent change in society. Hence, it entails "changing the character and attitude of individuals concerned[;] ... change by force, without a "change of heart," merely substitutes one master or evil for another' (Brown 1961: 20-21, see also Dees 1998). Servant leadership often plays a critical role in social change programs (Hickman 2010), including social enterprises (e.g., Martin and Novicevic 2010). Servant leadership has nine functional attributes, namely: vision, honesty, integrity, trust, service, 
modeling, pioneering, appreciation of others, and empowerment (Russel and Stone 2002). Let us discuss them in the context of Vinoba led Bhoodan.

Figure 1. Bhoodan: An Instance of Servant Leadership and Social Entrepreneurship

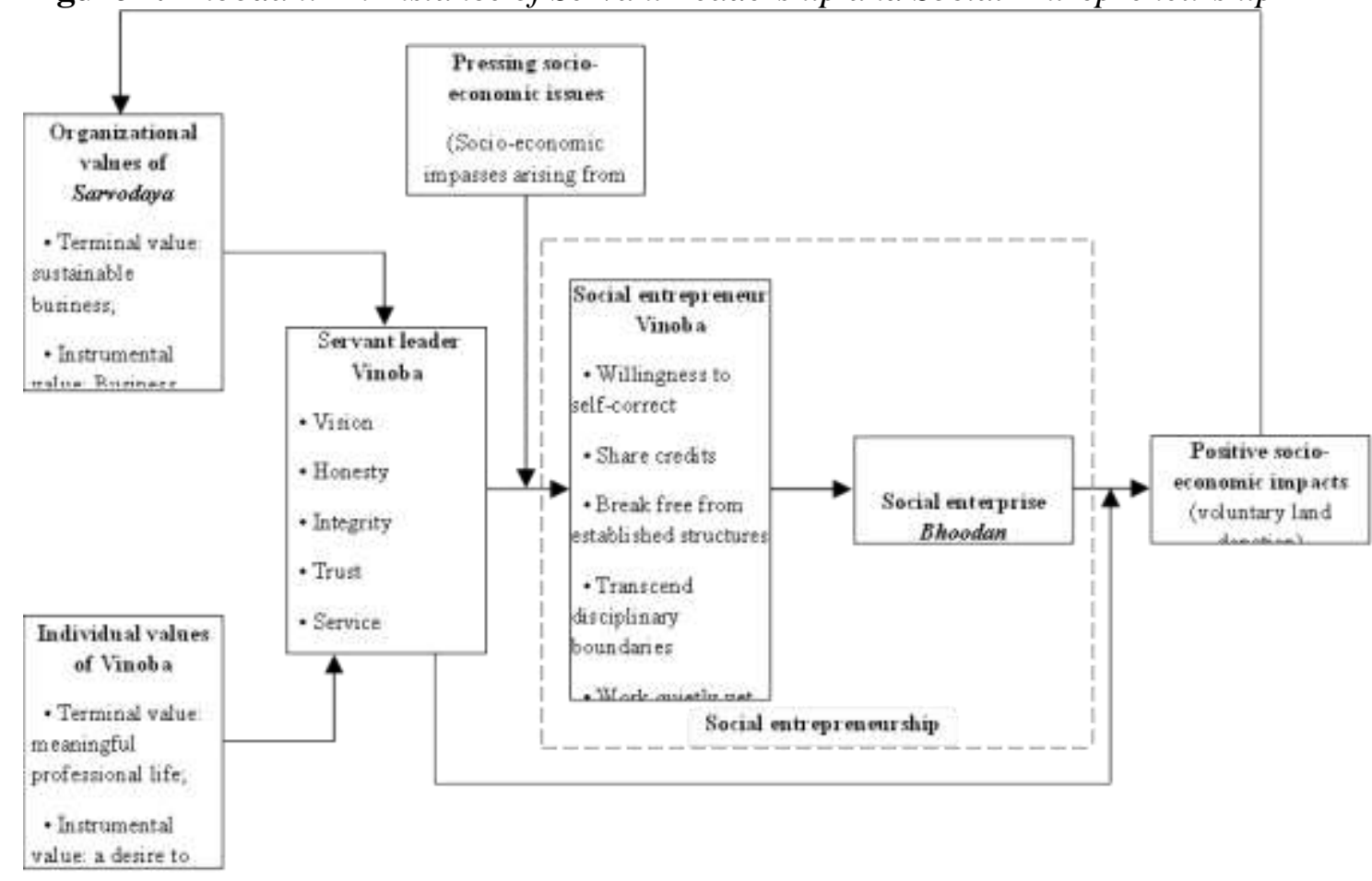

Source: Van Dierendonck (2011: 1233); Russel and Stone (2002: 154).

\section{The Other Side of Bhoodan: A Critique}

Bhoodan was timely, strategic, and produced social impacts with mixed results. In the 1950s and 1960s, when rural India had a sizeable share in the national economy and when most parts of India was reeling under violent peasant unrests, land reform was important. He therefore launched Bhoodan. In the early 1960s, when eastern India faced a major food crisis, he diversified focus toward fostering cooperation among people and increasing land productivity by creating Shramdan (Bandyopadhyay 2008). And, when Bhoodan sensitized the government machinery about the importance of equitable land ownership, which promulgated land reform laws, he scaled down Bhoodan in 1967. 
Table 1. SWOT Analysis of Bhoodan

\begin{tabular}{|c|c|}
\hline Strengths & Weaknesses \\
\hline $\begin{array}{l}\text { 1. Futuristic vision and time-bound objective } \\
\text { mission } \\
\text { 2. Organizational strength, resource } \\
\text { mobilisation, creative strategy, servant } \\
\text { leadership, and passionate involvement (of all) } \\
\text { 3. Apt timing and launching } \\
\text { 4. Stakeholder diversity } \\
\text { 5. Direct, personal and face-to-face interaction } \\
\text { 6. Inclusive form of governance and } \\
\text { management }\end{array}$ & $\begin{array}{l}\text { 1. Lofty goals } \\
\text { 2. Absence of clarity regarding the objective } \\
\text { 3. Mostly one-man show and taken-for- } \\
\text { granted personal beliefs of the leader } \\
\text { 4. Being operational in a society } \\
\text { overcrowded with too many problems } \\
\text { 5. Initial success led complacency } \\
\text { 6. Ran into many other programs } \\
\text { 7. Operating under more emotional beliefs, } \\
\text { and less rational thoughts } \\
\text { 8. Non-existence of a Plan B }\end{array}$ \\
\hline Opportunities & Threats \\
\hline $\begin{array}{l}\text { 1. Futuristic vision led sustainability and } \\
\text { objective mission led short-term success } \\
\text { accomplishment } \\
\text { 2. The evolution of the 'sprit of volunteering' } \\
\text { among Indians }\end{array}$ & $\begin{array}{l}\text { 1. Goal waywardness and difficulties in } \\
\text { impact assessment due to overcrowding of } \\
\text { programs } \\
\text { 2. Absence of an alternative plan and hence } \\
\text { project's weaker self-adjustment possibility }\end{array}$ \\
\hline
\end{tabular}

Source: Author.

Bhoodan had its shortcomings too. (See: Table 1) First, up to three-fourths of the collected land was due to the personal influence of Vinoba; when he withdrew from the Movement, "it lost its mass base" (Hazra 2006: 33). Second, landlords mostly donated unproductive land, evaded the land ceiling regulations, and betrayed Bhoodan in the process (Nedumpara 2004). Third, Bhoodan was financed by regional governments in India, like Bihar, to frustrate the demands of peasants (Nedumpara 2004). Fourth, the distribution of Bhoodan land was often lengthy and intricate (Linton 1972). Fifth, many meagre land-holders gave away land under Bhoodan, and expected more land under Gramdan (Church 1975). Sixth, the relationship between the landowners and landless was far from cordial in many cases; thus, removal of social and economic barriers did not happen (Nanekar and Khandewale 1973). Seventh, in the absence of financial assistance, the poor peasants were exploited by traditional money lenders who were landlords (Nanekar and Khandewale 1973). Eighth, Bhoodan had a diverse stakeholder profile; however, a movement, to be successful, should have support from fairly homogeneous groups (Oommen 1972: 77). Ninth, some of the most important Bhoodan leaders used their clout to launch anti-governmental activities to gain political mileage (Nedumpara 2004). Tenth, Bhoodan became a "system maintaining device" (Oommen 1972: 3) - it served the feudal interests of the rich (landlords) - because the land that were donated under its auspices became government land under Zamindari Abolition Act and hence could not be distributed under Bhoodan (Oommen 2009 [1969]). Vinoba also acknowledged that Bhoodan's tilt toward the rich instead of the poor was fundamentally flawed, because the rich almost did everything to defeat its purpose (Bhave 2009 [1969]). Furthermore, the servant leadership served the cause of Bhoodan well in the initial period. When the movement became bigger and complex, e.g., the introduction of Gramdan, Vinoba should have adopted transformational leadership (Smith et al. 2004). 
Furthermore, Bhoodan's shortcomings chiefly led to the "second awakening of peasant movement" or the Naxalite movement in the late 1960s, when peasants demanded the implementation of land reforms, which still is continuing (Hardiman 2003: 207-210). The landlords also created their own armed gangs, in some cases with the support of the government, which is still prevalent (Nedumpara 2004). Hence, Bhoodan could not create amity between the landlords and the landless. Moreover, the landlessness has not been addressed till date. The Eleventh Five Year Plan ${ }^{2}$ (2007-2012) reveals the continuance of oral and concealed tenancy in rural areas. As a result, tillers' position remains precarious (Planning Commission, Government of India: 67). This has raised serious doubts about the effectiveness of land reform. Notwithstanding, Bhoodan is appreciated as "the first step [toward] ... a total revolution [to create a fair and equitable society]" (Sherman 2016).

\section{Bhoodan-Based Corporate Citizenship (BbCC)}

Bhoodan was launched to solicit voluntary land donations when agriculture was the lifeline of the economy. Things at present are different, though. The World Bank (2015) data reveals that the overindulgence in the occupations in the primary sector, like farming, has resulted in India's low per capita GDP. Although, India's economic growth has reduced poverty (Bhagwati and Panagariya 2013), it still has 380 million people who live on less than a dollar a day (Kornblum 2012). Hence, India's policymakers are emphasizing upon manufacturing and service sectors for economic development.

Since independence, successive governments have emphasized on urbanization and industrialization for economic growth (Bhagwati and Panagariya 2013). India is currently the fastest growing major economy in the world (IMF, 2016). This momentous growth is the outcome of largescale industrialization, urbanization, and infrastructure projects (World Bank 2016), which involve massive statemanaged land acquisitions (Chakravorty 2013). But land acquisition through eminent domain is emerging as "India's 'biggest problem"" because it has created poor stakeholder management (Chakravorty 2016: 49). Consequently, the judiciary and legislature are at loggerheads. For example, on a petition filed by farmers, the highest court of Madhya Pradesh recently quashed land acquisition by the state to develop an industrial park (Times of India 2017). Thus, land acquisition "has now become a major bone of contention between farmers and those who need land for commercial [purpose]; ... leading to social unrest and violence" (Bardhan 2011: 55). People are distrustful about government and business regarding land acquisition. This is a situation marred by trust deficit between the haves (land-owners and users) and the have-nots (those who need resource rich land), which is similar to India's post-independence era. Noting the similarities between now and in the 1950s, we argue that the tenets of Bhoodan are useful here.

\footnotetext{
${ }^{2}$ The Indian economy is based in part on planning over five year durations.
} 
On the one hand, land is needed to be transferred for commercial purpose; it should be done amicably for the long-term progress of all, on the other. Like Vinoba, business can see this situation as an opportunity. In this regard, we propose a corporate citizenship program based on servant leadership influenced social entrepreneurship: Bhoodan-based corporate citizenship (hereafter BbCC). (BbCC is in line with Figure 1.) Whereas Bhoodan was an attempt to create voluntary land donations because the poor landless population was its major beneficiary, $\mathrm{BbCC}$ is proposed to facilitate spontaneous land transfers. This is because land is transferred by the land-owners and users who are mainly poor and marginalized; hence, they need compensation to have better and alternative livelihoods. To overcome weaknesses and threats concerning Bhoodan, we propose corrective mechanisms into BbCC.

\section{Corporate Citizenship and Structural and Functional Aspects of BbCC}

According to Crane et al. (2008), companies as extended citizens, instead of the governments, can provide social, civil, and political rights to people. They can facilitate welfare rights for ordinary citizens, further (or suspend) human rights, or act as channels through which citizens may express their political opinions and exercise their political rights. $\mathrm{BbCC}$ is based on this extended corporate citizenship program.

$\mathrm{As} \mathrm{BbCC}$ is a vehicle to further commercial interests of business as well as meet the social and economic aspirations of people, BbCC's leader should be ideally a company insider having the traits of both a servant leader and a social entrepreneur. To instill legitimacy and authority into the servant leader, company's top decision-makers along with chief sustainability officer and chief human resource officer should oversee the selection process. Following Boehm (2002), we assume that chief sustainability officer can represent the local community which is critical for the effectiveness of socially responsible programs.

$\mathrm{BbCC}$ attempts to create a social enterprise that facilitates spontaneous land transfers by the land-owners and users. Its servant leadership side ensures fair compensation and the social entrepreneurship side its prudent usage for sustained income. In addition to company personnel, it comprises of diverse stakeholders like land-owners and users, community opinion leaders, social reformers including religious leaders, NGOs, local politicians, government bureaucrats at the village and district levels like the police, like-minded industry representatives, and the United Nations Global Compact (UNGC). The UNGC not only aims to create a more sustainable and inclusive world but also, being a United Nations body, is respected and trusted. It is argued that such a multi-stakeholder oriented social enterprise is helpful to address pressing social problems (see Sud et al. 2009). For effectiveness, the BbCC leader, like Vinoba, should create a coalition constituted by members from the above stakeholder profile, which can create the social change, i.e., spontaneous land transfers (see Kotter 1996: 66). Coalition size may be determined as per requirement. When the program needs fast-tracking, the BbCC leader should employ a small group because smaller groups are faster at completing tasks, and if the goal is fact-finding, larger groups should be employed 
(Robbins and Judge 2013). BbCC should be named uniquely, say, an important local cultural aspects, which can foster members' identity toward it (Tajfel and Turner 1979).

Let us now discuss the functional aspects of BbCC. After studying the situation related to land acquisition, the BbCC leader, with the help of the stakeholder coalition, should spread awareness and create a "sense of urgency" (Kotter 1996: 42-44) among the stakeholders about the importance of resource rich land for a thriving business that eventually can lead to community prosperity and national progress. This, we anticipate, would lessen local hostility toward business (see Boehm 2002) and also bestow social rights (right to education) to landowners and users (Crane et al. 2008), e.g., skill building education and money management and training programs for the land-owners and users.

As land is an emotional issue in India (Porwal and Singh 2011), land acquisition should not merely emphasize upon a "profit first" motivation; rather, it should be done with "the sole purpose of achieving a union of hearts [between business and the landowners by strategically aligning their interests]" (Shepard 1987: 11). The BbCC leader and the coalition should be aware of and abide by the legal aspects regarding land acquisition, e.g., analyzing environmental impacts, giving fair compensations, obtaining eighty percent land-owners and users consent, and so on, which can bestow civil rights (right to property) to landowners and users (Crane et al. 2008). BbCC should not indulge in "land grabbing" which will defeat the entire process. Thus, it should give political rights (right to dissent) to land-owners and users (Crane et al. 2008). This means, its modus operandi should be transparent and it should be accountable to the community.

All along, the BbCC leader should be careful about being focused on the task in hand, i.e., spontaneous land transfers, and as far as possible stay away from other socio-economic issues in the community. The BbCC leader should always look for avenues to self-correct the corporate citizenship program like pursuing alternative plans and even disbanding the program altogether if the need arises. Finally, we argue that the positive socio-economic impacts in the form of actual spontaneous land transfers can influence organizational values, transform organizational culture, and make an organization a 'good' corporate citizen (see Schein 2010). This can create social legitimacy, enhancing the organizational trustworthiness as a sustainable societal change agent in the process.

\section{Discussion, Contributions, Limitations, and Future Research Directions}

India's current land acquisition practices are unsustainable. Trust deficit due to past abuses between land-owners and users on one side and, the government and business on the other is a major stumbling block to streamline this impasse. Doing business as usual by accommodating the interests of traditionally powerful stakeholders, like government and business, and ignoring the interests of imperceptible stakeholders, like the land-owners and users, has created poor stakeholder management. This is a situation of lost opportunities for both business and society. Top-down approaches employing social, economic, political, and 
legal means have not improved the situation. Hence, we have suggested a multistakeholder grass-root centric means to bridge trust deficit between land-owners and users and business. Borrowing tenets from Bhoodan and employing servant leadership and social entrepreneurship, we propose BbCC as an extended corporate citizenship program that can enable spontaneous land transfer by the land-owners and users, thereby streamlining various impasses in the land acquisition. In particular, following van Dierendonck (2011), we conceptualize $\mathrm{BbCC}$ bestow social, civil, and political rights to land-owners and users like Bhoodan as a as a social enterprise, which we posit can facilitate spontaneous land transfer. In the process, we make several contributions to research and practice.

\section{Theoretical Contributions}

BbCC can contribute to the literature on justice in general and justice as fairness in particular It satisfies Rawls' (1971[1999]) justice as fairness in the following manner. It ensures that economic equity must not override social equality. This is important because "social and economic gains (permitted by the second principle) cannot be achieved by sacrificing the equal scheme of basic liberties (specified by the first principle)" (Mandle 2009: 48). In this context, bestowing social, civil, and political rights to land-owners and users through BbCC is an attempt to satisfy Rawls' (1971[1999]) principle of liberty (Barry 1973), which can create spontaneous land transfers leading to satisfying the boundary conditions of Rawls' (1971[1999]) difference principle (Beauchamp 1980, Feldman 1996, Nozick 2013 [1974]).

\section{Practical Implications}

From the practitioners' perspective, business can immensely benefit from $\mathrm{BbCC}$. At present, there are severe trust deficits between business and land-owners and users because of the past atrocities (Ghatak and Ghosh 2011). BbCC can be act as a justice restoration mechanism in society, which can make business once again a trustworthy social institution. In this regard, the most prominent feature of $\mathrm{BbCC}$ is the collective decision-making process to acquire land, which can create a bottom-up democratic approach to facilitate spontaneous land transfers. Additionally, BbCC can serve the interests of land-owners and users by bestowing upon them social and civil rights; and empower them by bestowing upon them political rights (Kell and Levin 2003, Berlin 1969). Thus, BbCC underlines that sustainable land acquisition needs corporate citizenship programs in countries like India that should first create conducive conditions for social projects by employing servant leadership and then spread them through social entrepreneurship (see Martin and Novicevic 2010).

\section{Limitations and Future Research Directions}

This is a conceptual paper that is based solely on a review of the extant literature. For future research, an empirical study can be conducted to obtain the 
veracity of BbCC. Further, there are limitations regarding BbCC as an extended corporate citizenship program. Although Goyder (1961) advocates that socially responsible business is 'good' business in the long run, Korten (1984) cautions that markets would discipline companies which are financially irresponsible and loss-making, despite being socially responsible. Hence, BbCC needs careful analysis of different societal (e.g., pressing socio-economic issues), organizational (e.g., organizational values), and individual (e.g., values and leadership styles) variables as its constituents. These interactions can also uncover different opportunities and threats of employing $\mathrm{BbCC}$ to streamline land acquisition related impasses, which can shed additional insights. For example, when BbCC encounters situations where societal norms and structures have led to a heavily ossified social problems, it may be "ecologically rational" to adopt constructive rule breaking to introduce innovations and reforms (Mulgan 2006: 82). After all, breaking free from established structures and transcending disciplinary boundaries are two of the essential qualities of social entrepreneurs (Bornstein 2007). Doing so may be tantamount to social activism, not corporate citizenship per se, which business may ignore. However, this type of corporate citizenship programs may be viewed as another form of corporate charity. This, we argue, can be yet another future study, i.e., to delineate the boundaries of BbCC.

\section{Conclusion}

Land acquisition is a classic case where economic progress has come at the cost of various ethical disgraces. One of its damaging consequences is the proliferation of sustainability challenges arising out of socio-environmental injustices that dampen the prospects of sustainable business. However, there is no denying that the spirit of entrepreneurship is important for India's progress. One of the salient features of entrepreneurship is to capitalize upon opportunities. In this context, we argue that business and land-owners and users can leverage upon the opportunity of spontaneous land transfers to create positive socio-economic impacts by facilitating spontaneous transfers of land. $\mathrm{BbCC}-\mathrm{a}$ fusion between servant leadership and social entrepreneurship - is a generative attempt in this regard that can enhance the quality and magnitude of positive socio-economic impacts in the context of land acquisition. Considering its sustainability features, we argue that $\mathrm{BbCC}$ is a means through which business can serve and empower the imperceptible stakeholders, namely land-owners and users in the context of land acquisition, which can create social and environmental justice, triple bottomline outcomes, and sustainable and inclusive development of India

\section{Bibliography}

Ahmed S, Varshney A (2012) Battles half won: Political economy of India's growth and economic policy since independence. In Ghate C (Ed) The Oxford handbook of the Indian economy, 56-102. New York: Oxford University Press. 
Amnesty International (2016) "When land is lost, do we eat coal?" Coal mining and the violations of Adivasi rights in India. Retrieved from https://bit.ly/2b7Hsga.

Baggett B (1997) Power Serve: 236 inspiring ideas on servant leadership. Germantown, TN: Saltillo Press.

Bandyopadhyay D (2008 March) Does Land Still Matter? Economic \& Political Weekly (8): 37-42.

Bardhan P (2011) Industrialization and the land acquisition conundrum. Development Outreach 13: 54-57.

Barry B (1973) John Rawls and the priority of liberty. Philosophy \& Public Affairs 2: 274-290.

Beauchamp T (1980) Distributive Justice and the Difference Principle. In Blocker HG, Smith EH (Eds) John Rawls's theory of social justice, 132-61. Athens, OH: Ohio University Press.

Bennis W, Nanus B (1997) Leaders: Strategies for taking charge. New York, NY: HarperCollins.

Berlin I (1969) Four essays on liberty. Oxford, UK: Oxford University Press.

Bhagwati JN, Panagariya A (2013) Why growth matters: How economic growth in India reduced poverty and the lessons for other developing countries. New York: Public Affairs.

Bharathi KS (1991) The social philosophy of Mahatma Gandhi. New Delhi, India: Concept Publishing.

Bhave AV (2009) Bhoodan Yagna. In Desai AR (Ed) Rural sociology in India, 629632 ( $5^{\text {th }}$ ed.). Mumbai, India: Popular Prakashan.

Boehm A (2002) Corporate Social Responsibility: A Complementary Perspective of Community and Corporate Leaders. Business and Society Review 107: 171-194.

Bornstein D (2007) How to change the world: Social entrepreneurs and the power of new ideas. New York, NY: Oxford University Press.

Brass PR (1994) The politics of India since independence, $2^{\text {nd }}$ ed. Cambridge, UK: Cambridge University Press.

Brown DM (1961) The nationalist movement: Indian political thought from Ranade to Bhave. Berkley, CA: University of California Press.

Brown J (2000) Nehru. Hoboken, NJ: Pearson Education.

Business Standard (2013) Once landowners, they now work as security guards. Retrieved from https://bit.ly/2Nm4de8.

Chakravorty S (2013) The price of land: Acquisition, conflict, consequence. New Delhi, India: Oxford University Press.

Chakravorty S (2016) Land acquisition in India: The political-economy of changing the law. Area Development and Policy 1: 48-62.

Chandra B, Mukherjee M, Mukherjee A (2008) India since independence, Revised ed. New Delhi, India: Penguin Books.

Church R (1975) Review: The Impact of Bhoodan and Gramdan on Village India. Pacific Affairs, 48: 94-98.

Clark M (2009) The social entrepreneur revolution: Doing good by making money, making money by doing good. London: Marshall Cavendish.

Collier D (1995) Translating quantitative methods for qualitative researchers: The case of selection bias. American Political Science Review 89: 461-466.

Covey SR (1996) Three roles of the leader in the new paradigm. In Hesselbein F, Goldsmith M, Beckhard R (Eds.) The leader of the future: New visions, strategies, and practices for the next era, 149-159. San Francisco, CA: Jossey-Bass.

Crane A, Matten D, Moon J (2008) Corporations and citizenship. Cambridge, UK: Cambridge University Press. 
Dees JG (1998) The Meaning of "Social Entrepreneurship." Retrieved from https://stan ford.io/2QusxMJ.

Dees JG, Emerson J, Economy P (2002) Editors' introduction. In Dees JG, Emerson J, Economy $\mathrm{P}$ (Eds.) Strategic tools for social entrepreneurs: Enhancing the performance of your enterprising non-profit, xxix-xxxvi. New York, NY: John Wiley.

Dias A (2009) Eminent domain, displacement and impoverishment. In Modi R (Ed) Beyond relocation: The imperative of sustainable resettlement, 183-198. New Delhi, India: Sage.

Drayton R (2000) Nature's Government: Science, imperial Britain, and the 'improvement' of the world. New Haven, CT: Yale University Press.

Drèze J, Sen A (2013) An uncertain glory: India and its contradictions. Princeton, NJ: Princeton University Press.

Dutta Mishra A, Narayanasamy S (2009) World crisis and the Gandhian way. New Delhi, India: Concept Publishing.

The Economic Times (2015) Land acquisition a difficult task in India: Arvind Panagariya. Retrieved from https://bit.ly/2E1Dc0e.

Economy P (2002) Leading, retaining, and rewarding people entrepreneurially. In Dees JG, Emerson J, Economy P (Eds) Strategic tools for social entrepreneurs: Enhancing the performance of your enterprising non-profit, 71-92. New York, NY: John Wiley.

Ellis F (1993) Peasant economics: Farm households in agrarian development, $2^{\text {nd }}$ ed. Cambridge, UK: Cambridge University Press.

Feldman F (1996) Responsibility as a condition for desert. Mind, 105: 165-168.

Fernandes W (2004) Rehabilitation policy for the displaced. Economic and Political Weekly 39: 1191-1193.

Fernandes W (2008) Displacement and land alienation from common property resources. In Mehta L (Ed) Displaced by development: Confronting marginalization and gender injustice, 105-129. New Delhi, India: Sage Publications.

Figueroa M (1997) Bhave, Vinoba (1895-1982). In Powers RS (Ed) Protest, power, and change: An encyclopedia of nonviolent action from ACT-UP to women's suffrage, 43-44. London: Taylor \& Francis.

Ghatak M, Ghosh P (2011) The land acquisition bill: A critique and a proposal. Economic and Political Weekly XLVI: 65-72.

Goswami A (2016) Land acquisition, rehabilitation and resettlement: Law, politics and the elusive search for balance. Journal of Land and Rural Studies, 4: 3-22.

Goyder G (1961) The responsible company. Oxford, UK: Blackwell Publishing.

Greenleaf RK (2002[1977]) Servant leadership: A journey into the nature of legitimate power and greatness, $25^{\text {th }}$ Anniversary ed. Mahwah, NJ: Paulist Press.

Hardiman D (2003) Gandhi in his time and ours: The global legacy of his ideas. London: C. Hurst \& Co.

Hazra A (2006) Land reforms: Myths and realities. New Delhi, India: Concept Publishing.

Hickman GR (2010) Leading change in multiple contexts: Concepts and practices in organizational, community, political, social, and global change settings. Thousand Oaks, CA: Sage.

Hindu (2015) Private interest as public purpose. Retrieved from https://bit.ly/2yfdVJR.

Hindustant Times (2016) 'SC hiked relief in 6 out of 10 cases of land acquisition'. Retrieved from https://bit.ly/2E8tZ6q.

Howell MC, Prevenier W (2002) From reliable sources: An introduction to historical methods. New York: Cornell University Press. 
International Monetary Fund (2016) World economic outlook update: Uncertainty in the aftermath of the U.K. referendum. Retrieved from https://bit.ly/2aiakll.

Indian Express (2016) Land acquisition bill: Consensus eluded Centre, now four states relax their land laws. Retrieved from https://bit.ly/2xXb4Wz.

Jaffrelot C (2012). The political guru: The guru as éminence grise. In Copeman J, Ikegame A (Eds) The Guru in South Asia: New interdisciplinary perspectives, 80-96. New York, NY: Routledge.

Jayapalan N (2003) Indian political thinkers: Modern Indian political thought. New Delhi, India: Atlantic Publishers and Distributors.

Kell G, Levin D (2003) The Global Compact network: An historic experiment in learning and action. Business and society Review 108: 151-181.

Kitzi J (2002) Managing your board entrepreneurially. In Dees JG, Emerson J, Economy P (Eds) Strategic tools for social entrepreneurs: Enhancing the performance of your enterprising non-profit, 93-116. New York, NY: John Wiley.

Kornblum W (2012) Sociology in a changing world. Belmont, CA: Wadsworth Cengage Learning.

Korten DC (1984) Strategic Organization for People-Centered Development. Public Administration Review 44: 341-352.

Kotter JP (1996) Leading change. Boston, MA: Harvard Business School Press.

Kouzes JM, Posner BZ (1995) The leadership challenge. San Francisco, CA: Jossey-Bass.

Levien M (2011) Special economic zones and accumulation by dispossession in India. Journal of Agrarian Change 11: 454-483.

Linton E (1972) Fragments of a vision: A journey through India's Gramdan villages. Varanasi, India: Sarva Seva Sangh Prakashan.

Lobo L, Kumar S (2009) Land acquisition, displacement and resettlement in Gujarat: 1947-2004. New Delhi, India: Sage.

Logsdon JM, Wood DJ (2002) Business citizenship: From domestic to global level of analysis. Business Ethics Quarterly 12: 155-87.

Mandle J (2009) Rawls's a theory of justice: An introduction. New York, NY: Cambridge University Press.

Martin JS, Novicevic M (2010) Social entrepreneurship among Kenyan farmers: A case example of acculturation challenges and program success. International Journal of Intercultural Relations 34: 382-392.

Martin MM (1998) Trust leadership. The Journal of Leadership Studies 5: 41-49.

McKay J (1976) The coalescence of history and archaeology. Historical Archaeology 10: 93-98.

Meehan B (2004) 15 Minutes with Bill Drayton, CEO of Ashoka. Stanford Social Innovation Review 1: 11-12.

Melkote SR, Steeves HL (2001) Communication for development in the third world: Theory and practice for empowerment. Thousand Oaks, CA: Sage.

Michael A, Baumann MM (2016) India and the dialectics of domestic and international "land grabbing": Historical perspectives, current debates, and the case of Ethiopia. India Review 15: 112-135.

Mingers J, Standing C (2017) Why things happen - Developing the critical realist view of causal mechanisms. Information and Organization 27: 171-189.

Mulgan G (2006) Cultivating the other invisible hand of social entrepreneurship: Comparative advantage, public policy, and future research priorities. In Nicholls A (Ed) Social entrepreneurship: New models of sustainable Social Change, 74-95. Oxford, UK: Oxford University Press.

Munshi D, Kurian P (2007) The case of the subaltern public: A postcolonial investigation of corporation social responsibility's (o) missions. In May S, Cheney G, Roper J 
(Eds) The debate over corporate social responsibility, 438-447. New York: Oxford University Press.

Nanekar KR, Khandewale SV (1973) Bhoodan and the landless. Bombay, India: Popular Prakashan.

Narain V (2009) Growing city, shrinking hinterland: Land acquisition, transition and conflict in peri-urban Gurgaon, India. Environment \& Urbanization 21: 501-512.

NCAS (2005) Advocacy update on land rights: Issue 18. New Delhi, India: National Centre for Advocacy Studies.

Nedumpara JJ (2004) Political economy and class contradictions: A study. New Delhi, India: Anmol Publications.

Nicholls A, Cho AH (2006) Social entrepreneurship: The structuration of a field. In Nicholls A (Ed) Social entrepreneurship: New models of sustainable social change, 99-118. Oxford, UK: Oxford University Press.

Nielsen KB (2015) Between peasant utopia and neoliberal dreams: Industrialisation and its discontents in emerging India. In Hansen A, Wethal U (Eds) Emerging economies and challenges to sustainability: Theories, strategies, local realities, 79-91. New York: Routledge.

NITI Aayog (n.d.) Land acquisition: Rationale and the way forward. Retrieved from https://bit.ly/2OGnyLE.

Nozick R (2013[1974]) Anarchy, state, and utopia. New York, NY: Basic Books.

Oommen TK (1972) Charisma, stability and change: An analysis of Bhoodan-Gramdan movement in India. New Delhi, India: Thompson Press.

Pirson M, von Kimakowitz E, Spitzeck H, Amann W, Khan S (2009) Introduction. In Spitzeck H, Pirson M, Amann W, Khan S, Kimakowitz E von, Humanism in Business, 1-12. New York, NY: Cambridge University Press.

Planning Commission of India (2014) Data-book compiled for use of planning commission. Retrieved from https://bit.ly/2CsiJ2N.

Planning Commission, Government of India (n.d.). Report of the Steering Committee on rapid poverty reduction and local area development for the eleventh five year plan (2007-2012). Retrieved from https://bit.ly/2Pf24m3.

Porwal V, Singh S (2011) Land acquisition and determination of land price: A critical appraisal of the existing and proposed normative framework as applied in Singrauli district, Madhya Pradesh. In Somayaji S, Talwar S (Eds) Development-induced displacement, rehabilitation and resettlement in India: Current issues and challenges, 61-74. New York: Routledge.

Rawls J (1999 [1971]) A theory of justice, Revised ed. Cambridge, MA: Harvard University Press.

Reuters (2016) Indian farmers at risk as states bypass land acquisition laws - activists. Retrieved from https://reut.rs/2QBqAOT.

Robbins SP, Judge TA (2013) Organizational behavior, 15 ${ }^{\text {th }}$ ed. Hoboken, NJ: Pearson/Prentice Hall.

Russel RF, Stone AG (2002) A review of servant leadership attributes: Developing a practical model. Leadership and Organization Development Journal 23: 145-157.

Sabin M (2002) Dissenters and mavericks: Writings about India in English, 1765-2000. New York, NY: Oxford University Press.

Sahoo P, Nataraj G, Dash RK (2014) Foreign direct investment in South Asia: Policy, impact, determinants and challenges. New Delhi: Springer.

Sarkar A (2012) Development, displacement, and food security: Land acquisition in India. In Ghate C (Ed), The Oxford handbook of the Indian economy, 311-340. New York: Oxford University Press. 
Schein EH (2010) Organizational culture and leadership, $4^{\text {th }}$ ed. San Francisco, CA: John Wiley.

Schwab K (2008) Global corporate citizenship: Working with governments and civil society. Foreign Affairs 87: 107-118.

Sethi SP (2002) Standards for corporate conduct in the international arena: Challenges and opportunities for multinational corporations. Business and Society Review 107: 2040.

Shepard M (1987) Gandhi today: The story of Mahatma Gandhi's successors. Santa Ana, CA: Seven Locks Press.

Sherman TC (2016) A Gandhian answer to the threat of communism? Sarvodaya and postcolonial nationalism in India. The Indian Economic and Social History Review 53: 249-270.

Singh R (2012) Inefficiency and abuse of compulsory land acquisition. Economic and Political Weekly 47: 46-53.

Singh SK (2009) Basic features of the Indian economy in 1947. In Chandhoke N, Priyadarshi P (Eds), Contemporary India: Economy, society, politics, 3-15. Noida, India: Dorling Kindersley (India).

Smith BN, Montagno RV, Kuzmenko TN (2004) Transformational and servant leadership: Content and contextual comparisons. Journal of Leadership \& Organizational Studies 10: 80-91.

Somayaji S, Talwar S (2011) Development-induced displacement, rehabilitation and resettlement in India: Current issues and challenges. In Somayaji S, Talwar S (Eds) Development-induced displacement, rehabilitation and resettlement in India: Current issues and challenges, 1-10. New York, NY: Routledge.

Sud M, VanSandt CV, Baugous AM (2009) Social Entrepreneurship: The Role of Institutions. Journal of Business Ethics 85: 201-216.

Supreme Court of India (2016) In the Supreme Court of India, Civil appellate jurisdiction: Civil appeal no.8438 of 2016 (Arising out of SLP (C) No.8463 of 2008). Retrieved from https://bit.ly/2y12rKm.

Tajfel H, Turner J (1979) An integrative theory of inter-group conflict. In Williams JA, Worchel S (Eds) The social psychology of inter-group relations, 33-47. Belmont, CA: Wadsworth

Tennyson H (1955) India's walking saint: The story of Vinoba Bhave. New York, NY: Doubleday.

The New York Times (2015) Indian opposition delays Modi's land-acquisition effort. Retrieved from https://nyti.ms/2OIBjtf.

The Times of India (2014) Crony capitalism a big threat to countries like India, RBI chief Raghuram Rajan says. Retrieved from https://bit.ly/1rhPDIi.

The World Bank (2015) GDP per capita (current US\$) Retrieved from https://bit.ly/1q AC44p.

Time (1953) India: A man on foot. Retrieved from https://ti.me/2NsY6ok.

Time (1956) India: Course of an ideal. Retrieved from https://ti.me/2PkBY1d.

Times of India (2017) HC quashes land acquisition proceedings for Diamond Park. Retrieved from https://bit.ly/2y6IdPo.

Ulrich D (1996) Credibility X capability. In F. Hesselbein, M. Goldsmith, \& R. Beckhard, The leader of the future: New visions, strategies, and practices for the next era, 209219. San Francisco, CA: Jossey-Bass.

Van Dierendonck D (2011) Servant leadership: A review and synthesis. Journal of Management 37: 1228-1261

Varshney A (1998) Democracy, development, and the countryside: Urban-rural struggles in India. Cambridge, UK: Cambridge University Press. 
Venkatasubbiah H (1961) Indian economy since independence. Bombay: Asia Publishing House.

Watanabe S (1972) Creative time. In Fraser JT, Haber FC, Muller GH (Eds) The study of time, 159-189. Berlin: Springer.

Weber T (2004) Gandhi as disciple and mentor. New York, NY: Cambridge University Press. 